\title{
The Bromotyrosine Derivative lanthelline Isolated from the Arctic Marine Sponge Stryphnus fortis Inhibits Marine Micro- and Macrobiofouling
}

Kine $\varnothing$. Hanssen, Gunnar Cervin, Rozenn Trepos, Julie Petitbois, Tor Haug, Espen Hansen, Jeanette H. Andersen, Henrik Pavia, Claire Hellio and Johan Svenson

\begin{abstract}
The inhibition of marine biofouling by the bromotyrosine derivative ianthelline, isolated from the Arctic marine sponge Stryphnus fortis, is described. All major stages of the fouling process are investigated. The effect of ianthelline on adhesion and growth of marine bacteria and microalgae is tested to investigate its influence on the initial microfouling process comparing with the known marine antifoulant barettin as a reference. Macrofouling is studied via barnacle (Balanus improvisus) settlement assays and blue mussel (Mytilus edulis) phenoloxidase inhibition. lanthelline is shown to inhibit both marine micro- and macrofoulers with a pronounced effect on marine bacteria (minimum inhibitory concentration (MIC) values $0.1-10 \mu \mathrm{g} / \mathrm{mL}$ ) and barnacle larval settlement $\left(\mathrm{IC}_{50}=3.0 \mu \mathrm{g} / \mathrm{mL}\right)$. Moderate effects are recorded on $M$. edulis $\left(\mathrm{IC}_{50}=45.2 \mu \mathrm{g} / \mathrm{mL}\right)$ and microalgae, where growth is more affected than surface adhesion. The effect of ianthelline is also investigated against human pathogenic bacteria. lanthelline displayed low micromolar MIC values against several bacterial strains, both Gram positive and Gram negative, down to $2.5 \mu \mathrm{g} / \mathrm{mL}$. In summary, the effect of ianthelline on 20 different representative marine antifouling organisms and seven human pathogenic bacterial strains is presented.
\end{abstract}

\section{Introduction}

Rapid colonisation and successive overgrowth of epibiotic organisms on a surface immersed in water is a process known as biofouling. It is a fast and complex sequence of events which is initiated by surface adhesion of organic molecules, followed by the rapid settlement of microfoulers (marine bacteria, protozoans and microalgae) and, subsequently, macrofoulers (macroalgae and invertebrates) (Qian et al. 2007; Yebra et al. 2004). Biofouling is a natural process, yet it is highly undesired for a wide range of marine economic sectors such as shipping, aquaculture and the offshore petroleum industry. The growth on associated man-made structures leads to substantial economic losses in these sectors mainly due to increased fuel usage, maintenance costs and process parameter interference (Yebra et al. 2004; Fitridge et al. 2012). Employment of antifouling (AF) paints has been the most successful strategy to prevent biofouling on such structures (Almeida et al. 2007). The most efficient AF compounds such as organotin and copper oxide have been shown to come with several serious environmental drawbacks (Okoro et al. 2011; Kotake 2012; Nakanishi 2008) due to the collateral damage inflicted on the marine environment and non-target species. The high toxicity and induction of imposex, i.e. the development of male characteristics by females, amongst marine molluscs (Ellis and Pattisina 1990; Nakanishi 2008) resulted in a total ban on the use of organotin-based compounds in the marine environment which was implemented in 2008. 
Not only man-made structures submerged in water but also sessile marine organisms such as sponges and tunicates serve as surfaces for biofouling and are under a constant threat of being overgrown by epibionts. Despite this, many sessile marine organisms appear to have developed strategies to combat epibiosis and maintain a clean exterior surface, free of settling species (Muller et al. 2013). This observation has motivated the search formarine compounds with AF activities from their arsenal of secondary metabolites (Tsukamoto et al. 1996a; Fusetani 2004, 2011; Hellio et al. 2005). Marine sponges in particular are a rich source of bioactive secondary metabolites, some with documented AF activity (Sipkema et al. 2005; Stowe et al. 2011; Gerwick and Moore 2012). Sponges are primitive sessile filter-feeders that lack a specialised immune system and the ability to remove themselves from predators and settling organisms. To prevail, they have developed physical and chemical defence strategies to protect themselves against over-growth by epibionts (Muller et al. 2013). Sponges commonly host a range of microbial symbionts that may produce compounds protecting their host. Sponges therefore represent a particularly rich marine source for discovering novel compounds (Gerwick and Fenner 2013; Gerwick and Moore 2012; Ortlepp et al. 2007).

One group of marine compounds described in the literature that display particular potential as antifoulants are bromotyrosine-derived sponge metabolites (Ortlepp et al. 2007). Several such compounds have been studied, and their inhibition of balanide larval settlement has been described (Ortlepp et al. 2007). Similar brominated marine compounds such as barettin and oroidin (Fig. 1) have also been extensively investigated as potential leads for additives in marine paints as "green" settlement deterrents (Sjogren et al. 2004b; Yamada et al. 1997). Both barretin and oroidon and their synthetic derivatives have been incorporated in paint formulations and shown to prevent biofouling in field studies (Melander et al. 2009; Sjogren et al. 2004a). Synthetic analogues of bromotyrosines isolated from sponges have further been shown to inhibit phenoloxidase frombluemussels at low micromolar concentrations (Bayer et al. 2011).

Following on the ban on organotin compounds, marine natural products have received an increased focus and have even been heralded as the way forward towards environmentally friendly AF solutions (Bhadury and Wright 2004; Marechal and Hellio 2009; Qian et al. 2010; de Nys and Steinberg 2002). Searches for such compounds within the phylum Porifera are ongoing and provide sound basis that an environmentally friendly compound may be isolated from marine sponges (Tsukamoto et al. 1996a; Santos Acevedo et al. 2013). Being of natural origin does not guarantee that the marine AF compounds are non-toxic, but they come with the advantage of having been tuned by evolution for their task. The ideal "green" AF compound should be deterring rather than toxic to the target species (Dobretsov et al. 2006; Marechal and Hellio 2009; Chambers et al. 2006).

In this study, we report the AF activities of ianthelline (1) (displayed in Fig. 1 together with structurally related marine AF compounds), a bromotyrosine derivative isolated from the Arctic sponge Stryphnus fortis (Hanssen 
et al. 2012). The structure of 1 was determined in 1986 (Litaudon and Guyot 1986), and its synthesis was recently described by Shearman et al. (2010).

Fig. 1 Structure of ianthelline (1) and structurally and marinerelated compounds that have been evaluated as AF compounds: 5,5'-dibromohemibastadin-1 (2), barettin (3) and oroidin (4)

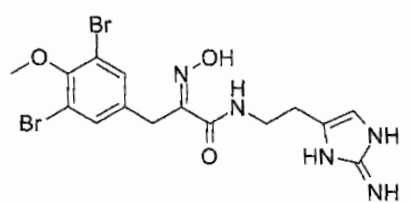

(1)

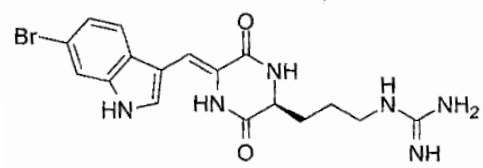

(3)

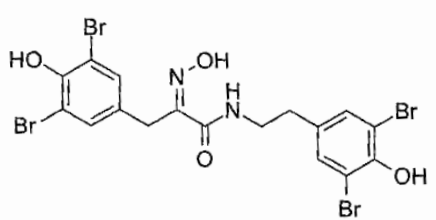

(2)

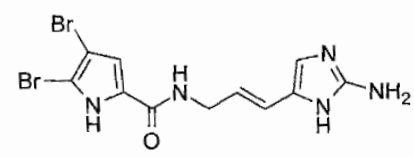

(4)

Compound 1 was originally isolated from the Caribbean sponge lanthella ardis and has been shown to be a major secondary metabolite in several other warm water sponges (Litaudon and Guyot 1986; Ciminiello et al. 1995). It is a bioactive compound, and the antitumoral activity of 1 was published in 2012 by Hanssen et al. (2012). The initial isolation paper briefly reported antibacterial and antifungal bioactivities against one bacterial and one fungal strain (Litaudon and Guyot 1986). Apart from those studies, little is known about the potential bioactivities of 1 , and its ecological role is not understood. A fractionated extract from the Caribbean sponge Aiolochroia crassa containing 1 has been reported to inhibit the attachment of marine bacteria to agar blocks (Kelly et al. 2003, 2005). The pooled fractionated extracts prepared in that particular study was studied at natural volumetric concentrations. Thus, the amount, purity, and bioactive concentration of 1 were unknown. The attachment inhibition of Vibrio harveyi was examined, and growth values ranging from 14 to 61 $\%$, compared to growth control, in five different fractions rich in 1 was reported (Kelly et al. 2005).

The optimisation of synthetic bromotyrosine derivatives for phenoloxidase inhibition revealed a pharmacophore that is highly analogous to the substructures displayed by 1 , suggesting additional bioactivities for 1 (Bayer et al. 2011). Compound 1 contains an oxime moiety, postulated by Proksch and coworkers, to be essential for AF activity, and it represents an interesting compound for further studies towards AF solutions (Ortlepp et al. 2007).

The present study is thus an important continuation of the previously limited studies of the bioactivity and potential ecological role of 1 and also represents an assessment of the exploitability of 1 for biotechnological and medical purposes. Herein, we describe how 1 is isolated from an Arctic source and tested in a wide array of assays (Svenson 2013). In the marine environment, biofouling is undertaken by a great diversity of species, and marine AF compounds should therefore ideally possess a broad-spectrum activity to contend with the 
vast amount of epibionts. The effect of 1 on the growth and settlement inhibition of ten marine bacterial and eight microalgal strains relevant to the formation of the biofouling film as well as studies on Balanus improvisus barnacle larvae settlement inhibition is described. A potential effect on bivalves is also studied using the Mytilus edulis phenoloxidase assay. Finally, the effect of 1 on a test panel of seven human pathogenic bacterial strains is investigated to evaluate the inhibitory effect on medically important strains. Comparisons with relevant structurally related, marine secondary metabolites are included and discussed.

\section{Materials and Methods}

Organism and Purification of 1 and 3

The specimen of $S$. fortis was collected off the coast of Spitsbergen $\left(79^{\circ} 33^{\prime} \mathrm{N}, 8^{\circ} 53^{\prime} \mathrm{E}\right)$ in September 2007. Extraction, purification and structure determination of 1 was carried out as previously described (Hanssen et al. 2012).

For comparison, 3 was isolated from Geodia barretti, collected off the coast of Troms $\varnothing$, Norway, in 2009. The compound was extracted according to previous methods and purified from a desalted $40 \%$ RP-SPE extract (Tadesse et al. 2008) using a Waters SunFire Prep C18 HPLC column (10×250 mm, $5 \mu \mathrm{m}$ particle size). A linear gradient from 15 to $30 \%$ acetonitrile in ultra-pure water containing $0.1 \%$ TFA $(v / v)$ was applied at $4 \mathrm{~mL} / \mathrm{min}$ over 50 min to elute 3. The compound was identified by high-resolution mass spectrometry (HR-MS and HRMS/MS) using a LTQ Orbitrap XL Hybrid Fourier Transform mass spectrometer (Thermo Fischer Scientific, MA, USA) and by comparison with previously published data on 3 (Lidgren and Bohlin 1986; Solter et al. 2002).

Marine Antibacterial Assays

Tenmarine bacterial strains from the bacterial collection of the University of Portsmouth School of Biological Sciences were used in the current study (Table 1).

Table 1 Marine bacterial strains used in the present study

Marine bacteria

Halomonas aquamarina

Polaribacter irgensii

Pseudoalteromonas elyakovii

Roseobacter litoralis

Shewanella putrefaciens

Vibrio aestuarianus

Vibrio carchariae

Vibrio harveyi

Vibrio natriegens

Vibrio proteolyticus

${ }^{1}$ American tissue culture code
ATCC1

14400

700398

700519

49566

8071

35048

35084

700106

14058

53559 
These selected strains are representative of fouling species in both estuarine and marine environments (Chambers et al. 2011). They were grown at $26^{\circ} \mathrm{C}$ in a marine medium, composed of $0.5 \%$ peptone (neutralised bacteriological peptone, Oxoid LTD) in filtered (Whatman 1,001-270, pore size $11 \mu \mathrm{m}$ ) natural seawater from the Solent (UK). Compounds 1 and 3 were dissolved in $100 \%$ methanol (general purpose grade, Fisher Chemical) and transferred to clear polystyrene 96-well plates (Fisher Scientific), dried under vacuum and sterilised under UV illumination. Wells were prepared using concentrations of $0.01,0.1,1$ and 10 $\mu \mathrm{g} / \mathrm{mL}$, and each concentration was replicated six times (Bressy et al. 2010). Both growth and adhesion inhibition were studied.

\section{- Growth inhibition experiments}

One hundred microlitres of bacterial culture $\left(2 \times 10^{8}\right.$ colony forming units (CFU) $\left.\mathrm{mL}^{-1}\right)$ was added to each well under aseptic conditions and incubated for $48 \mathrm{~h}$ at $26^{\circ} \mathrm{C}$. The minimum inhibitory concentration (MIC) was defined as the minimum concentration resulting in no change in optical density at $630 \mathrm{~nm}$ after incubation for $48 \mathrm{~h}$ (Thabard et al. 2011).

\section{- Adhesion inhibition experiments}

Microplates were prepared and inoculated as stated above. After a 48-h incubation, wells were emptied and rinsed once with $100 \mu \mathrm{L}$ of sterile seawater to remove the non-attached cells and air-dried at room temperature. The remaining bacterial biofilm was stained with $100 \mu \mathrm{L}$ of $0.3 \%(v / v)$ aqueous crystal violet, and the optical density (OD) was measured at $595 \mathrm{~nm}$ (Sonak and Bhosle 1995).

Media was used as blank, and MIC was defined as the lowest concentration that produced a reduction in adhesion.

\section{Microalgal Assay}

Eight pure, but non-axenic, marine microalgae (obtained from Algobank, Caen, France) were used in this study (Table 2).

Table 2 Microalgae used in the present study

Microalgae

Cylindrotheca closterium

Exanthemachrysis gayraliae Halamphora coffeaeformis Pleurochrysis roscoffensis Porphyridium purpureum Hymenomonas coronata Rhodosorus marinus Pleurochrysis carterae
Algobank code

AC 170

AC 15

AC 713

AC 32

AC 122

AC 115

AC 119

AC 1 
All the included strains are involved in surface colonisation and can lead to increased rates of biocorrosion (Jellali et al. 2013). Each algal strain was grown for 5 days prior to use at $20^{\circ} \mathrm{C}$ in $\mathrm{F} / 2$ medium. After 5 days, microalgal concentration was assessed via analysis of the chlorophyll $a$ content (Chambers et al. 2011), and dilutions of the stock culture were made accordingly to generate stock solutions of each microalgae containing $0.1 \mathrm{mg} / \mathrm{L}$ chlorophyll a. One hundred microlitres of the stock solutions were transferred to the wells of black 96-well plates prepared with ranging concentrations of 1 and 3 as described above. Both adhesion and growth inhibition were studied.

\section{- Growth inhibition experiments}

The inoculated plates were grown for 5 days under constant light exposure $\left(140 \mu \mathrm{mol} \mathrm{m}^{-2} \mathrm{~s}^{-1}\right)$ at $20^{\circ} \mathrm{C}$. After the incubation, the microplates were centrifuged at $4,100 \mathrm{rpm}$ for $10 \mathrm{~min}$ at $4^{\circ} \mathrm{C}$ using a Beckman Coulter Allegra 25R centrifuge and subsequently emptied. One hundred microlitres of $100 \%$ methanol was added to each well to liberate chlorophyll $a$. The pigment concentration was quantified employing the fluorimetric method (Chambers et al. 2011). MIC values were calculated as explained for bacteria (based on OD measurements).

\section{- Adhesion inhibition experiments}

Black microplates were prepared and inoculated as stated above. Media was used as blank. After 5 days of incubation, the medium was gently removed using a multichannel pipette to eliminate all the non-attached cells. One hundred microlitres of $100 \%$ methanol was then added to each well to liberate chlorophyll $a$. The pigment concentration was quantified employing the fluorimetric method explained above.

\section{Balanus Cyprid Settlement}

Cyprid larvae of B. improvisus were reared in a laboratory cultivating system at Tjärnö Marine Biological Laboratory, as described by Berntsson et al. (2000). The settlement assays with B. improvisus cyprids were conducted in non-treated polystyrene Petri dishes ( $\varnothing 48 \mathrm{~mm}$, Nunc \#150340) containing $10 \mathrm{~mL}$ filtered $(0.2$ $\mu \mathrm{m}$ ) seawater. Compound 1 was dissolved in DMSO and then serially diluted with DMSO to give the desired concentration series of which $10 \mu \mathrm{L}$ was added to each test dish. A total of 18-22 newly moulted cyprids were added to each test dish which were incubated at room temperature $\left(20-25^{\circ} \mathrm{C}\right)$ for 5 days. At the end of the experiment, the number of metamorphosed juvenile barnacles, as well as live and dead cyprids, was assessed under a dissectionmicroscope. Each concentration of 1 was replicated four times $(n=4)$, and dishes with $10 \mu \mathrm{L}$ DMSO served as controls. The concentration of 1 leading to 50\%inhibition of the settlement compared to the control was reported as the $\mathrm{IC}_{50}$ value. 
Inhibition of Phenoloxidase from the Blue Mussel M. edulis

Phenoloxidase was isolated from the byssus gland of the blue mussel (M. edulis) as previously described (Hellio et al. 2000; Bayer et al. 2011). Solutions of $1 \mathrm{mg} / \mathrm{mL}$ M. edulis phenoloxidase, $0.4 \mathrm{mM}$ L-dihydroxyphenylalanine (DOPA), and $1(2-2,000 \mu \mathrm{g} / \mathrm{mL})$ were prepared. One millilitre of the LDOPA solution, $10 \mu \mathrm{L} 1$ (or $10 \mu \mathrm{L}$ of water in the case of the control samples), and $10 \mu \mathrm{L}$ M. edulis phenoloxidase (added last) were mixed in a test tube. Phosphate buffered saline $(\mathrm{pH} 6.8)$ was added to the solution tomake a total volume of $2 \mathrm{~mL}$. The solution was placed in a cuvette, and the change in absorbance at $475 \mathrm{~nm}$ was measured after 30 min using a UV-VIS spectrophotometer. The blank control used was the sample without the enzyme solution. The assay was run in triplicate, and the concentration of 1 leading to $50 \%$ inhibition of the phenoloxidase activity result was reported as the $\mathrm{IC}_{50}$ value.

Terrestrial Antibacterial Assay

The MIC of 1 was determined against seven human pathogenic bacterial strains presented in Table 3 .

Table 3 Human pathogenic bacterial strains used in the current study

Bacterial strain

ATCC

Gram positive

Staphylococcus aureus 25923

MRSA 33591

Staphylococcus epidermidis 35984

Streptococcus agalactiae $\quad 12386$

Enterococcus faecalis 29212

Gram negative

Escherichia coli 25922

Pseudomonas aeruginosa 27853

Enterococcus faecalis and Streptococcus agalactiae were grown in brain-heart infusion broth (BHI; Oxoid, Hampshire, England). Staphylococcus aureus, methicillin-resistant S. aureus (MRSA), Escherichia coli and Pseudomonas aeruginosa were grown in Mueller Hinton Broth (MH; Merck, Darmstadt, Germany), and Staphylococcus epidermidis in tryptic soy broth (TS; Merck, Darmstadt, Germany). Both growth and biofilm inhibition studies were performed.

\section{- Growth inhibition experiments}

Suspended bacteria in log phase grown at $37^{\circ} \mathrm{C}$ in growth medium were added to 96 -well microtiter plates resulting in 1,500-15,000 CFU/mL. A serial dilution of 1 was subsequently added and left to inoculate for $24 \mathrm{~h}$ before growth inhibition was observed with a Victor multilabel counter at $600 \mathrm{~nm}$. Growth medium diluted with water (1:1) was used as negative control, and bacteria suspension diluted with water (1:1) was used as positive control. Gentamicin at ranging concentrations from 0.015 to $16 \mu \mathrm{g} / \mathrm{mL}$ was used as positive assay 
control. The MIC was defined as the minimum concentration resulting in no change in optical density after incubation for $24 \mathrm{~h}$ at $37^{\circ} \mathrm{C}$. Compound 1 was tested at concentrations ranging from 2.5 to $160 \mu \mathrm{g} / \mathrm{mL}$.

- Inhibition of biofilm formation

S. epidermidis was used to assess the effect of 1 on biofilm formation. An overnight culture of S. epidermidis grown in TS was diluted with fresh TS containing $1 \%$ glucose (1:100). Aliquots of $50 \mu \mathrm{L}$ were transferred to a 96-well microtiter plate, and $50 \mu \mathrm{L}$ of 1 , dissolved in water at ranging concentrations, was added. After overnight incubation at $37^{\circ} \mathrm{C}$, the bacterial suspension was carefully discarded and the wells washed with water. The plate was dried and the biofilm fixed by incubation for $1 \mathrm{~h}$ at $55^{\circ} \mathrm{C}$ before the surface attached cells were stained with $100 \mu \mathrm{L}$ of $0.1 \%$ crystal violet for $5 \mathrm{~min}$. The crystal violet solution was removed and the plate once more washed with water and dried at $55^{\circ} \mathrm{C}$ for $1 \mathrm{~h}$. After adding $70 \mu \mathrm{L}$ of $70 \%$ ethanol, the plate was incubated at room temperature for $10 \mathrm{~min}$. Biofilm formation was observed by visual inspection of the plates. The MIC was defined as the lowest concentration where no biofilm formation was visible. A S. epidermidis suspension, diluted with $50 \mu \mathrm{L}$ of water, was used as a positive control, and $50 \mu \mathrm{L}$ Staphylococcus haemolyticus suspension with $50 \mu \mathrm{L}$ of water was employed as a negative control. A mixture of $50 \mu \mathrm{L}$ water and $50 \mu \mathrm{L}$ TS was used as assay control.

\section{Results and Discussion}

Biofouling is a complex chemical and biological process, and no single bioassay can be used to accurately imitate it. Several different assays and organisms are hence needed to evaluate the AF potential of a compound (Briand 2009; Dahms and Hellio 2009). The progression from adsorption of organic molecules to a marine surface to the growth of macroepibionts such as macroalgae, crustaceans and mussels also involves microorganisms such as bacteria and microalgae. It is therefore unrealistic to assume that a single non-toxic AF compound will display activity against all organisms associated with it. In fact, limited access to comprehensive screens against all the different stages of the AF process may lead to the discovery of promising compounds that are later shown to be inactive in complementary studies against other types of foulers (Qian et al. 2010). In the current study of 1, we have included bioassays targeting the main groups of marine organisms involved in the different stages of the biofouling process. The well-established AF brominated diketopiperazine barettin (3), isolated from G. barretti, was included for comparison and as a reference in selected assays.

The initial microfouling of bacteria and microalgae was studied via both adhesion and growth inhibition assays. It is generally accepted that the microfouling can facilitate the macrofouling (Beech et al. 2005; Qian et al. 2007). Targeting the initial settlement and production of these marine biofilms may thus have beneficial effects for limiting the fouling of macroorganisms. The presence of such marine biofilms on surfaces also increases the rate of biocorrosion (Beech and Sunner 2004). The growth inhibition was studied via standard 
serial dilution methods against ten relevant marine bacterial strains. Since biofouling is a process associated with the adhesion of organisms to a surface, the study of bacterial attachment is highly relevant and that was therefore also studied for the same bacterial strains. In addition, eight microalgal strains including the diatoms Cylindrotheca closterium and Halamphora coffeaeformis were also studied. Diatoms represent particularly relevant strains as they commonly rapidly form resilient slimy layers on marine surfaces (Molino and Wetherbee 2008). The data from the microorganism screening is compiled in Table 4.

Table 4 The effect of 1 and 3 on growth and adhesion of fouling marine bacteria and microalgae

\begin{tabular}{|c|c|c|c|c|}
\hline \multirow[t]{2}{*}{ Microorganism } & \multicolumn{2}{|c|}{ MIC $1(\mu \mathrm{g} / \mathrm{mL})$} & \multicolumn{2}{|c|}{ MIC $3(\mu \mathrm{g} / \mathrm{mL})$} \\
\hline & Growth & Adhesion & Growth & Adhesion \\
\hline \multicolumn{5}{|l|}{ Marine bacteria } \\
\hline Halomonas aquamarina & $>10$ & $>10$ & $>10$ & $>10$ \\
\hline Polaribacter irgensii & 1 & $>10$ & $>10$ & $>10$ \\
\hline Pseudoalteromonas elyakovii & 1 & $>10$ & $>10$ & $>10$ \\
\hline Roseobacter litoralis & 1 & $>10$ & $>10$ & $>10$ \\
\hline Shewanella putrefaciens & 0.1 & $>10$ & 10 & $>10$ \\
\hline Vibrio aestuarianus & 0.1 & 0.1 & 0.01 & $>10$ \\
\hline Vibrio carchariae & $>10$ & $>10$ & $>10$ & $>10$ \\
\hline Vibrio harveyi & 10 & $>10$ & $>10$ & $>10$ \\
\hline Vibrio natriegens & $>10$ & 0.1 & $>10$ & 10 \\
\hline Vibrio proteolyticus & 10 & $>10$ & 10 & $>10$ \\
\hline \multicolumn{5}{|l|}{ Microalgae } \\
\hline Cylindrotheca closterium & $>10$ & $>10$ & 0.1 & 0.1 \\
\hline Exanthemachrysis gayraliae & $>10$ & $>10$ & $>10$ & $>10$ \\
\hline Halamphora coffeaeformis & $>10$ & $>10$ & $>10$ & $>10$ \\
\hline Pleurochrysis roscoffensis & 10 & $>10$ & $>10$ & $>10$ \\
\hline Porphyridium purpureum & $>10$ & $>10$ & 0.1 & 1.0 \\
\hline Hymenomonas coronata & 1 & n.d. ${ }^{1}$ & n.t. ${ }^{2}$ & n.t. ${ }^{2}$ \\
\hline Rhodosorus marinus & 1 & n.d. ${ }^{1}$ & n.t. $^{2}$ & n.t. $^{2}$ \\
\hline Pleurochrysis carterae & 0.1 & n.d. ${ }^{1}$ & n.t. $^{2}$ & n.t. $^{2}$ \\
\hline
\end{tabular}

${ }^{1}$ Not determined due to unfavourable growth conditions for the adhesion study ${ }^{2}$ Not tested

Only concentrations of 1 at or below $10 \mu \mathrm{g} / \mathrm{mL}$ were evaluated for the microorganism studies. This represents a threshold for compounds to be regarded as highly active and of further interest from a biotechnological viewpoint (Hellio et al. 2009). From Table 4, it is clear that 1 has a pronounced effect on the inhibition of marine bacterial growth. All the tested marine bacteria are Gram-negative, and most display MIC values below $10 \mu \mathrm{g} / \mathrm{mL}$, some as low as $0.1 \mu \mathrm{g} / \mathrm{mL}$. Only the growth of three bacteria (Halomonas aquamarina, Vibrio carchariae and Vibrio natriegens) of the tested ten strains tested remained unaffected by 1 at $10 \mu \mathrm{g} / \mathrm{mL}$, illustrating a strong and broad antibacterial activity. In the bacterial adhesion studies, the MIC values were higher. Only the two Vibrio species $V$. natriegens and Vibrio aestuarianus displayed high sensitivity against 1 with MIC values of $0.1 \mu \mathrm{g} / \mathrm{mL}$. The high sensitivity of $V$. natriegens in the adhesion assay is of interest as it displayed a MIC $>10 \mu \mathrm{g} / \mathrm{mL}$ in the growth assay. $V$. natriegens is a very rapidly growing sulfate-reducing bacterium found on microfouled surfaces (Cheng et al. 2009). Sulfate-reducing bacteria are especially known for their role in biocorrosion (Beech and Sunner 2004), and finding a compound inhibiting the adhesion of $V$. 
natriegens would be highly interesting for reducing the biocorrosion process. The oyster industry has grown to be very important for many regions of the world, contributing substantially to social and economic activity in the coastal zones. V. aestuarianus is a known pathogen of the commercial pacific oyster Crassostrea gigas (Labreuche et al. 2006; De Decker et al. 2011) causing massive mortality outbreaks and a shortage in shellfish. Compound 1 inhibited the growth and adhesion of $V$. aestuarianus at very low concentrations.

In previous studies, 1 has been included in unspecified natural concentrations which are most likely significantly higher than those in the current study. This is based on the amounts of similar brominated secondary metabolites found and analysed in other tropical sponge extracts which frequently contain such compounds (e.g. oroidin, aeroplysinin and sceptrin) in high $(0.8-4.9 \mathrm{mg} / \mathrm{mL}$ ) natural volumetric concentrations (Kelly et al. 2003). S. fortis is also rich in 1, and approximately $0.05 \%$ of the organism wet weight is 1 , indicating that it is an important secondary metabolite. The antibacterial activity of 1 is similar to the bromotyrosine derivative zamamistatin isolated from the Okinawan sponge Pseudoceratina purpurea by Takada et al. (2001). In comparison to 3, which is both structurally related and a thoroughly studied marine AF compound, 1 displays a higher antibacterial activity. Compound 3 previously isolated from G. barrette was included in the antimicrobial assay and was active against both Vibrio proteolyticus and Shewanella putrefaciens at $10 \mu \mathrm{g} / \mathrm{mL}$ and highly active (MIC=0.01 $\mu \mathrm{g} / \mathrm{mL}$ ) against $V$. aestuarianus in analogy to 1 . In the bacterial adhesion assay, 3 was only active at $10 \mu \mathrm{g} / \mathrm{mL}$ against $V$. natriegens. No other bacterial strains were affected in the concentration range employed.

Microalgae forms slimy layers on marine surfaces that are generally challenging to prevent (Molino and Wetherbee 2008), and it was shown that 1 was active against half of the tested microalgal strains. Hymenomonas coronata, Rhodosorus marinus and Pleurochrysis carterae were all sensitive to 1 in solution with MIC values ranging from 0.1 to $1 \mu \mathrm{g} / \mathrm{mL}$ while Pleurochrysis roscoffensis displayed a MIC value of 10 $\mu \mathrm{g} / \mathrm{mL}$. The other four strains, including the two diatom species, were unaffected at the tested concentrations. In analogy to the bacterial studies, microalgal adhesion was also evaluated. No effect on algal adhesion was seen for 1 . Growth conditions for the three most sensitive species in the growth assay were unfavourable at the time of the adhesion studies, and no data could be obtained for those species. No algal toxicity was seen upon extended exposure times. In contrast, 3 was active against both the growth and adhesion of the diatom C. closterium at $0.1 \mu \mathrm{g} / \mathrm{mL}$ and Porphyridium purpureum at 0.1 and $1 \mu \mathrm{g} / \mathrm{mL}$, respectively.

The major macrofoulers, barnacles and mussels, were studied via both enzyme and settlement inhibition assays. Attachment of bivalves was studied by inhibition studies of phenoloxidase isolated from the byssus gland of the common blue mussel, M. edulis. Inhibition of the production of byssus threads by mussels has become an established method for evaluating their settlement (Hellio et al. 2000). Other marine invertebrates such as barnacle larvae also depend on phenoloxidase for generating a secure surface attachment. The 
function of phenoloxidase is to oxidise both phenylalanine and tyrosine in protein secretions to quinone derivatives that crosslink to generate a strong biopolymer enabling the organism to anchor to a surface (Bayer et al. 2011). The release of active phenoloxidase is controlled by $\mathrm{Ca}^{2+}$-dependent signalling pathways, and therefore, the intracellular concentration of $\mathrm{Ca}^{2+}$ is thus also an interesting target for the development of $\mathrm{AF}$ strategies. An inhibitory effect of 1 on phenoloxidase was seen at $1 \mu \mathrm{g} / \mathrm{mL}$, and the $\mathrm{IC}_{50}$ was determined to $45.2 \mu \mathrm{g} / \mathrm{mL}$. Such an $\mathrm{IC}_{50}$ suggests only moderate affinity of 1 for the phenoloxidase despite the $\alpha$-oxo-oxime functionality previously reported to be beneficial for blue mussel phenoloxidase inhibition. The synthetic 5,5'dibromohemibastadin-1 (2 in Fig. 1 ) is a strong phenoloxidase inhibitor with an $\mathrm{IC}_{50}$ value of $0.84 \mu \mathrm{g} / \mathrm{mL}$ (Bayer et al. 2011). Compounds 1 and 2 share several structural features such as the dibrominated phenol ring, the overall molecular length and the placement of the $\alpha$-oxo-oxime functionality. The $\alpha$-oxooxime functionality has been shown to be involved with complexation of the two copper(II) ions coordinated by six histidine residues in the catalytic centre of the phenoloxidase (Kim and Uyama 2005), and the oxime functionality was crucial for the strong inhibition of synthetic bastadin derivatives (Bayer et al. 2011). The main structural differences between 2 and 1 lie in the methoxylated phenolic hydroxyl in 1 and the cationic iminoimidazole ring. The inhibitory effect of 1 was reduced by nearly 50 -fold in comparison to 2 , and it is clear that the $\alpha$-oxooxime functionality is not sufficient for a high affinity interaction with the catalytic site of the enzyme given the other structural features of 1 . Compound 1 is also positively charged, and charge repulsion within the active site of phenoloxidase is a potential explanation for the lower inhibitory activity of 1 . The lack of a phenolic hydroxyl is also believed to additionally impair the enzyme binding as it represents the natural enzyme substrate binding motif (Kim and Uyama 2005).

While phenoloxidase inhibition is a common representative indicator of a compound's ability to reduce the settling abilities for a range of invertebrates (Bayer et al. 2011), studies on B. improvisus larvae were also performed to assess the potential effects 1 may specifically have on barnacles. Based on the moderate phenoloxidase inhibition, a similar moderate deterring effect on Balanus settlement was anticipated. The most commonly studied barnacle in AF studies is Balanus amphitrite which is found in tropical waters. The sponge S. fortis (Fig. 2), from which 1 was isolated, is a cold water species which is why we in this study chose to target B. improvisus, which is also found in cold water. From a chemical ecology perspective, it has been established that when working on marine natural products, it is more judicious to sample organisms and also test them primarily on fouling species from the same area (Marechal and Hellio 2011). B. improvisus is commonly found in the shallow littoral zone attached to stones, algae or man-made constructions (Barnes and Barnes 1962). It is a notorious fouler on smooth artificial substrates such as ship hulls, which has enabled its rapid spread amongst continents during the last century. The species has a planktotrophic larval development consisting of six naupliar stages and one non-feeding cyprid stage, the latter being responsible for finding and attaching to a suitable substratum. The processes of attachment and metamorphosis of the cyprid larva into an adult barnacle are collectively referred to as settlement. The cyprids are capable of exploring surfaces actively, and the site of settlement is determined using physical and biochemical properties 
of the substratum (Berntsson et al. 2000). The effect of 1 on B. improvisus cyprid larvae is presented below in Fig. 3.

Fig. 2 A specimen of S. fortis from which 1 was isolated for the present study. Scale bar represents $2 \mathrm{~cm}$

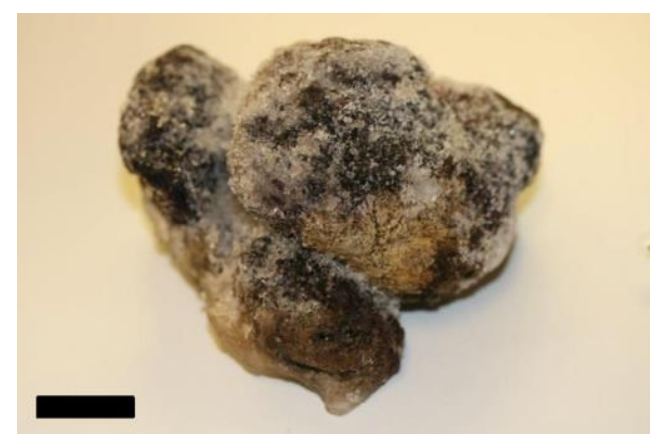

Fig. 3 Effect of 1 on the settlement of B. improvisus cyprid larvae as presented as percentages of settled (dark grey columns) and dead cyprids (light grey columns) and given as means $\pm S E(n=4)$. I $C_{50}$ was determined to 3.0 $\mu \mathrm{g} / \mathrm{mL}$. $0.1 \%$ DMSO $(v / v)$ in FSW was used as negative control

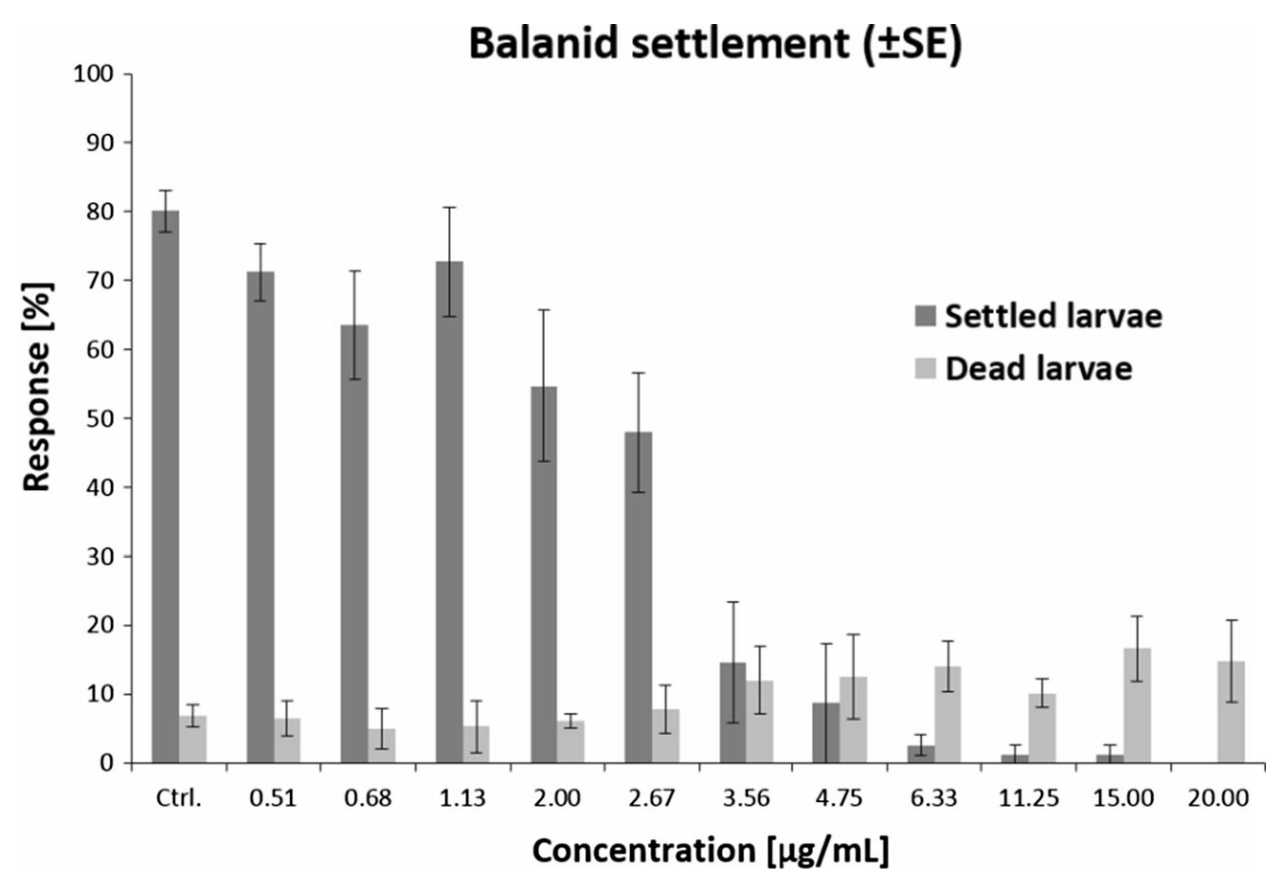

As evident from the settlement and metamorphosis inhibition data, 1 represents a potent AF compound against $B$. improvisus cyprid larvae. An $\mathrm{IC}_{50}$ of $3.0 \mu \mathrm{g} / \mathrm{mL}$ indicates a high deterring effect and makes 1 significantly more active against balanide settlement thanmost reported bromotyrosinederived sponge metabolites and their synthetic analogues (Ortlepp et al. 2007; Tsukamoto et al. 1996a). Compound 1 is four times as active as 2, and no apparent coupling between the moderate phenoloxidase inhibition and Balanus settlement is seen for 1 , as has been previously reported for the synthetic hemibastadins (Bayer et al. 2011). Compound 3 displays an $\mathrm{IC}_{50}$ around $1 \mu \mathrm{g} / \mathrm{mL}$ (Sjogren et al. 2004b) while the structurally related dibromopyrrole oroidin (4 in Fig. 1) exhibits an $\mathrm{IC}_{50}$ of $19 \mu \mathrm{g} / \mathrm{mL}$ against the settlement and metamorphosis of B. amphitrite cyprids (Tsukamoto et al. 1996b). Compound 1 displays activity similar to Ceratinamide B but is one order of magnitude less active than Ceratinamide A, a highly potent AF bromotyrosine derivate with low 
toxicity isolated from the marine sponge $P$. purpurea (Tsukamoto et al. 1996a). Even at the highest concentration tested $(20 \mu \mathrm{g} / \mathrm{mL}), 1$ exhibited low toxicity. Furthermore, an increase in larval time in the water column caused by settlement inhibition will inevitably result in higher larval mortality, which may partly explain the tendency for a higher cyprid mortality at the highest test concentrations of 1 (Fig. 3).

When the isolation of 1 was initially reported by Litaudon and Guyot in 1986, an activity against S. aureus using a disc diffusion assay ( $15 \mathrm{~mm}$ growth inhibition radius using a disc loaded with $50 \mu \mathrm{g}$ of 1 ) was included (Litaudon and Guyot 1986). Based on that initial data, a screening against human pathogenic bacterial strains was also performed to provide a comprehensive overview of the antibacterial effects of 1 . Both strains resistant to conventional antibiotics and biofilm forming bacteria were included in the test panel of seven bacterial strains. Serial dilution experiments were performed to assess the antibacterial activity of 1 against human pathogenic bacterial strains, and the data is compiled in Table 5.

Table 5 Antibacterial activity of 1 against human pathogenic bacterial strains

$\begin{array}{ll}\text { Bacterial strain } & \mathrm{MIC}(\mu \mathrm{g} / \mathrm{mL}) \\ \text { Gram positive } & \\ \quad \text { Staphylococcus aureus } & 2.5 \\ \text { MRSA } & 20 \\ \quad \text { Staphylococcus epidermidis } & 50 \\ \quad \text { Streptococcus agalactiae } & 7.5 \\ \quad \text { Enterococcus faecalis } & 22.5 \\ \text { Gram negative } & \\ \quad \text { Escherichia coli } & 7.5 \\ \quad \text { Pseudomonas aeruginosa } & 7.5 \\ \text { Biofilm inhibition } & \\ \quad \text { Staphylococcus epidermidis } & 30\end{array}$

The Gram-positive bacteria displayed sensitivities towards 1 ranging from 2.5 to $50 \mu \mathrm{g} / \mathrm{mL}$ while the two Gram-negative strains were both highly sensitive with MIC values of $7.5 \mu \mathrm{g} / \mathrm{mL}$. S. aureus displayed the highest sensitivity towards 1 at $2.5 \mu \mathrm{g} / \mathrm{mL}$, and the methicillin-resistant strain was slightly more tolerant. These activities are similar to those reported for synoxazolidinone A which is a closely structurally related marine compound isolated from the Arctic ascidian Synoicum pulmonaria (Tadesse et al. 2010). In this molecule, the central oxime is replaced with an oxazolidinone core. Previous cytotoxicity studies indicate that 1 does not act via cellular membrane disruption against mammalian cells (Hanssen et al. 2012). Instead, the kill kinetics suggests intracellular targets as no biological effect was seen until cells were incubated with 1 for extended periods and at higher concentrations. Even though the antibacterialmode of action of 1 was not studied in detail, it appears from the data that the antibacterial effect is primarily induced at the bacterial membrane interface. The rapid killing, once a threshold concentration on 1 has been reached, is typical for a compound acting by a nonspecific membrane depolarisation mechanism (Shai 1999) and is exemplified for selected strains in Fig. 4. 
Fig. 4 Effects of 1 on selected bacterial strains illustrating the threshold concentrations needed for activity, particularly against Gram-positive bacteria

S. agalactiae

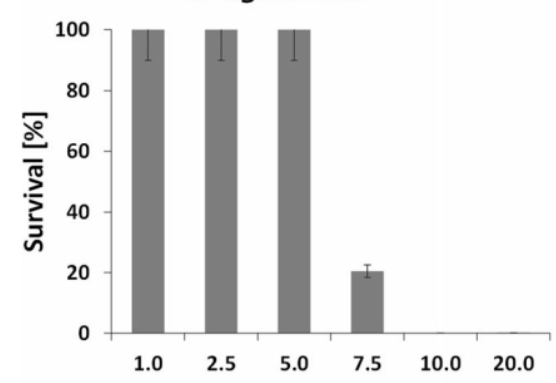

P. aeruginosa

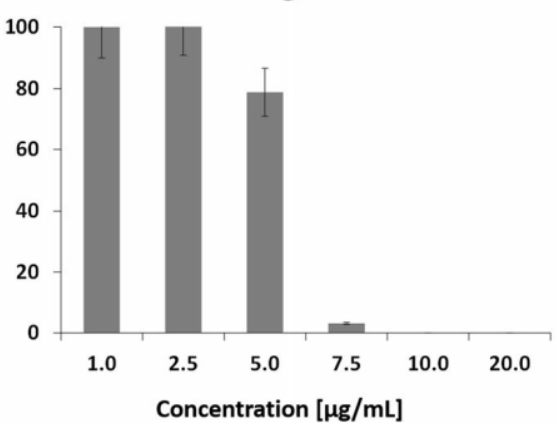

E. coli

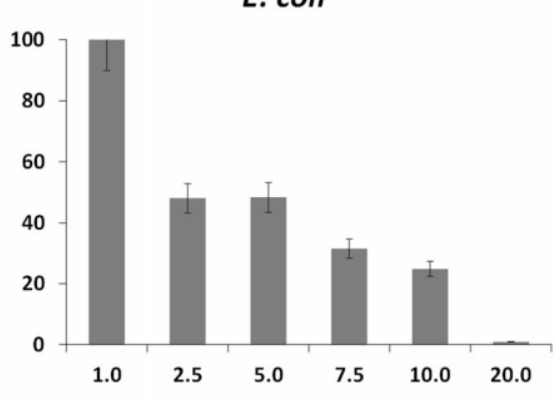

The lipid composition of the bacterial cell membrane differs significantly from the neutral mammalian cell membrane (Lohner et al. 2008), and a different mode of action on the anionic bacterial cell membrane is suspected. Cationic amphiphilic antimicrobial peptidic derivatives, which 1 can be regarded as, are generally active at the bacterial membrane interfaces via several mechanisms (Melo et al. 2009), and a pronounced antibacterial effect can be seen even for small diand tripeptidomimetics (Flaten et al. 2011). The inhibition of S. epidermidis biofilm formation at $30 \mu \mathrm{g} / \mathrm{mL}$ is seen at a lower concentration than the MIC for growth inhibition and may suggest an additional mode of action for 1 .

Given the many promising bioactivities of 1 and the relative ease of preparing it, and similar analogues, synthetically (Shearman et al. 2010; Ortlepp et al. 2007) it is realistic to assume that libraries of analogues of 1 is within reach. Compound 1 can be dissected into smaller building blocks allowing for alternative molecular assemblies where the key functional groups such as the tyrosine moiety, the central oxime and the cationic iminoimidazole can be substituted with analogous chemistries. Several different structural motifs displayed by 1 can be thus be targeted to generate diverse libraries of compounds that would aid in future structure activity relationship studies (SAR) as depicted in Fig. 5.

Fig. 5 Synthetic targets for structure activity relationship studies for establishing the AF pharmacophore of 1

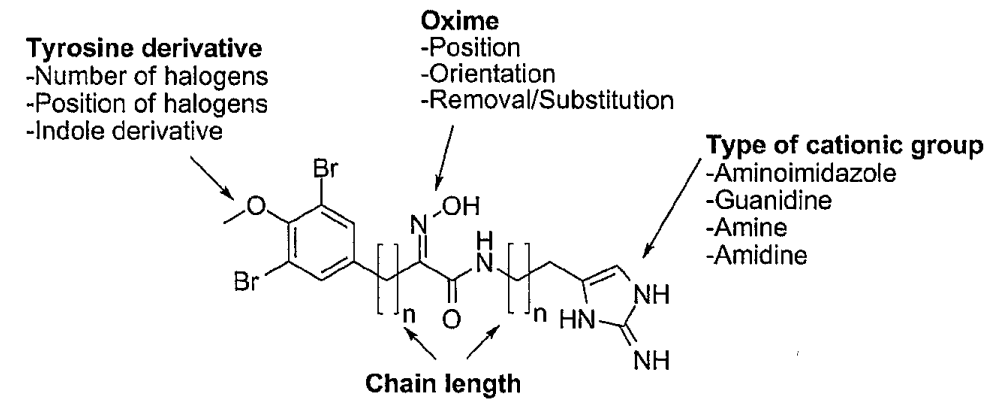

It is expected that such analogues will be active in several assays and also structurally simplified in comparison with one. This is certainly a prerequisite if a large-scale marine use is considered. The structurally related two 
has undergone extensive SAR studies, and those libraries of synthetic analogues have been shown to display several medically relevant bioactivities (Richards et al. 2008, 2009) and are being studied further.

The studied extract of $S$. fortis contains a range of secondary metabolites (unpublished data), but 1 is by far the most abundant compound constituting $0.05 \%$ of the organism's wet weight. This strongly indicates that 1 serves important ecological functions such as inhibition of the recruitment of potential epibionts and competitors, maybe in synergy with other compounds. A tissue specific production or localisation of 1 to exposed areas of the organism may further aid to increase the local concentration to levels higher than those evaluated in the present study to effectively prevent settlement to generate a broad resistance against competing marine species.

\section{Conclusion}

Brominated secondary metabolites are common in the marine environment, and the sponge-derived tyrosine derivatives are particularly interesting due to their diverse bioactivities and their potential application areas. In the present study, 1 was shown to be a powerful micro- and macro-AF compound, mainly against marine bacteria and the settlement of barnacles. A lower activity is seen against microalgae, and a moderate bioactivity is reported for blue mussel phenoloxidase inhibition. In addition, 1 is active against all tested human pathogenic bacterial strains included in the current study, both Gram positive and Gram negative. Based on the structural similarities with barettin, oroidin and the synoxazolidinones, it is anticipated that ianthelline also exhibits other biological activities yet to be investigated.

\section{Acknowledgments}

Marte Albrigtsen is acknowledged for performing the terrestrial bacterial screen, and Robert Andre Johansen is acknowledged for providing the photograph of $S$. fortis. The authors are further grateful to Dr. Lindon Moodie (UiT) for linguistic support and to Runar Gjerp Solstad (UiT) for purifying a sample of barettin. The study was performed at MabCent which is a centre for research-based innovation at the UiT and supported by the Research Council of Norway, Grant no 174885/130. HP and GC were supported by the Centre for Marine Chemical Ecology at the University of Gothenburg. 


\section{References}

Almeida E, Diamantino TC, De Sousa O (2007) Marine paints: the particular case of antifouling paints. Prog Org Coat 59:2-20

Barnes H, Barnes M (1962) The distribution and general ecology of Balanus balanoides together with some observations on Balanus improvisus in the waters around the coasts of Denmark, southern Sweden and northeast Germany. Acta Uni Lund 58:1-41

Bayer M, Hellio C, Marechal JP, FrankW, LinWH, Weber H, Proksch P (2011) Antifouling bastadin congeners target mussel phenoloxidase and complex copper(ii) ions. Mar Biotechnol 13:1148-1158

Beech WB, Sunner J (2004) Biocorrosion: towards understanding interactions between biofilms and metals. Curr Opin Biotechnol 15:181-186

Beech IB, Sunner JA, Hiraoka K (2005) Microbe-surface interactions in biofouling and biocorrosion processes. Int Microbiol 8:157-168

Berntsson KM, Jonsson PR, Lejhall M, Gatenholm P (2000) Analysis of behavioural rejection of micro-textured surfaces and implications for recruitment by the barnacle Balanus improvisus. J ExpMar Biol

Ecol 251:59-83

Bhadury P, Wright PC (2004) Exploitation of marine algae: biogenic compounds for potential antifouling applications. Planta 219:561-578

Bressy C, Hellio C, Marechal JP, Tanguy B, Margaillan A (2010) Bioassays and field immersion tests: a comparison of the antifouling activity of copper-free poly(methacrylic)-based coatings containing tertiary amines and ammonium salt groups. Biofouling 26:769-777

Briand JF (2009) Marine antifouling laboratory bioassays: an overview of their diversity. Biofouling 25:297-311

Chambers LD, Stokes KR, Walsh FC, Wood RJK (2006) Modern approaches to marine antifouling coatings. Surf Coat Technol 201: 3642-3652

Chambers LD, Hellio C, Stokes KR, Dennington SP, Goodes LR, Wood RJK, Walsh FC (2011) Investigation of Chondrus crispus as a potential source of new antifouling agents. Int Biodeterior Biodegrad 65:939-946 
Cheng S, Tian JT, Chen SG, Lei YH, Chang XT, Liu T, Yin YS (2009) Microbially influenced corrosion of stainless steel by marine bacterium Vibrio natriegens: (i) corrosion behavior. Math Sci Eng C-Biol 29:751-755

Ciminiello P, Fattorusso E, Magno S, Pansini M (1995) Chemistry of Verongida sponges. 4. Comparison of the secondary metabolite composition of several specimens of Pseudoceratina crassa. J Nat Prod 58:689-696

Dahms HU, Hellio C (2009) Laboratory bio-assays for screening marine antifouling compounds. In: Hellio C, Yebra DM (eds) Advances in marine antifouling coatings and technologies. Woodhead Publishing, New York

De Decker S, Normand J, Saulnier D, Pernet F, Castagnet S, Boudry P (2011) Responses of diploid and triploid pacific oysters Crassostrea gigas to vibrio infection in relation to their reproductive status. J Invertebr Pathol 106:179-191

De Nys R, Steinberg PD (2002) Linking marine biology and biotechnology. Curr Opin Biotechnol 13:244-248 Dobretsov S, Dahms HU, Qian PY (2006) Inhibition of biofouling by marine microorganisms and their metabolites. Biofouling 22:43-54

Ellis DV, Pattisina LA (1990) Widespread neogastropod imposex - a biological indicator of global TBT contamination. Mar Pollut Bull 21:248-253

Fitridge I, Dempster T, Guenther J, De Nys R (2012) The impact and control of biofouling inmarine aquaculture: a review. Biofouling 28: 649-669

Flaten GE, Kottra G, Stensen W, Isaksen G, Karstad R, Svendsen JS, Daniel H, Svenson J (2011) In vitro characterization of human peptide transporter hPEPT1 interactions and passive permeation studies of short cationic antimicrobial peptides. J Med Chem 54: 2422-2432

Fusetani N (2004) Biofouling and antifouling. Nat Prod Rep 21:94-104

Fusetani N (2011) Antifouling marine natural products. Nat Prod Rep 28: 400-410

GerwickWH, Fenner AM (2013) Drug discovery from marine microbes. Microb Ecol 65:800-806

Gerwick WH, Moore BS (2012) Lessons from the past and charting the future of marine natural products drug discovery and chemical biology. Chem Biol 19:85-98 
Hanssen KO, Andersen JH, Stiberg T, Engh RA, Svenson J, Geneviere AM, Hansen E (2012) Antitumoral and mechanistic studies of ianthelline isolated from the arctic sponge Stryphnus fortis. Anticancer Res 32:42874297

Hellio C, Bourgougnon N, Le Gal Y (2000) Phenoloxidase (ec 1.14.18.1) from the byssus gland of Mytilus edulis: purification, partial characterization and application for screening products with potential antifouling activities. Biofouling 16:235-244

Hellio C, Tsoukatou M, Marechal JP, Aldred N, Beaupoil C, Clare AS, Vagias C, Roussis V (2005) Inhibitory effects of Mediterranean sponge extracts and metabolites on larval settlement of the barnacle Balanus amphitrite. Mar Biotechnol 7:297-305

Hellio C, Marechal JP, DaGama BP, Pereira RC, Clare AS (2009) Natural marine products with antifouling activities. In: Hellio C, Yebra DM (eds) Advances in marine antifouling coatings and technologies. Woodhead Publishing, New York

Jellali R, Campistron I, Pasetto P, Laguerre A, Gohier F, Hellio C, Pilard JF, Mouget JL (2013) Antifouling activity of novel polyisoprenebased coatings made from photocurable natural rubber derived oligomers. Prog Org Coat 76:1203-1214

Kelly SR, Jensen PR, Henkel TP, Fenical W, Pawlik JR (2003) Effects of Caribbean sponge extracts on bacterial attachment. Aquat Microb Ecol 31:175-182

Kelly SR, Garo E, Jensen PR, Fenical W, Pawlik JR (2005) Effects of Caribbean sponge secondary metabolites on bacterial surface colonization. Aquat Microb Ecol 40:191-203

Kim YJ, Uyama H (2005) Tyrosinase inhibitors from natural and synthetic sources: structure, inhibition mechanism and perspective for the future. Cell Mol Life Sci 62:1707-1723

Kotake Y (2012) Molecular mechanisms of environmental organotin toxicity in mammals. Biol Pharm Bull $35: 1876-1880$

Labreuche Y, Lambert C, Soudant P, Boulo V, Huvet A, Nicolas JL (2006) Cellular and molecular hemocyte responses of the pacific oyster, Crassostrea gigas, following bacterial infection with Vibrio aestuarianus strain 01/32. Microbes Infect 8:2715-2724 
Lidgren G, Bohlin L (1986) Studies of Swedish marine organisms. 7. A novel biologically-active indole alkaloid from the sponge Geodia baretti. Tetrahedron Lett 27:3283-3284

Litaudon M, Guyot M (1986) lanthelline, a new derivative of 3,5-dibromo-tyrosine isolated from the sponge lanthella-ardis from the Bahamas. Tetrahedron Lett 27:4455-4456

Lohner K, Sevcsik E, Pabst G (2008) Liposome-based biomembrane mimetic systems: implications for lipidpeptide interactions. In: Liu AL (ed) Advances in planar lipid bilayers and liposomes. Elsevier, Amsterdam

Marechal JP, Hellio C (2009) Challenges for the development of new non-toxic antifouling solutions. Int J Mol Sci 10:4623-4637

Marechal JP, Hellio C (2011) Antifouling activity against barnacle cypris larvae: do target species matter (Amphibalanus amphitrite versus Semibalanus balanoides)? Int Biodeterior Biodegrad 65:92-101

Melander C, Moeller PDR, Ballard TE, Richards JJ, Huigens RW, Cavanagh J (2009) Evaluation of dihydrooroidin as an antifouling additive in marine paint. Int Biodeterior Biodegrad 63:529-532

Melo MN, Ferre R, Castanho M (2009) Opinion antimicrobial peptides: linking partition, activity and high membrane-bound concentrations. Nat Rev Microbiol 7:245-250

Molino PJ, Wetherbee R (2008) The biology of biofouling diatoms and their role in the development of microbial slimes. Biofouling 24: 365-379

Muller WEG, Wang XH, Proksch P, Perry CC, Osinga R, Garderes J, Schroder HC (2013) Principles of biofouling protection in marine sponges: a model for the design of novel biomimetic and bioinspired coatings in the marine environment? Mar Biotechnol 15: 375-398

Nakanishi T (2008) Endocrine disruption induced by organotin compounds; organotins function as a powerful agonist for nuclear receptors rather than an aromatase inhibitor. J Toxicol Sci 33:269-276

Okoro HK, Fatoki OS, Adekola FA, Ximba BJ, Snyman RG (2011) Sources, environmental levels and toxicity of organotin in marine environment-a review. Asian J Chem 23:473-482

Ortlepp S, SjogrenM, DahlstromM,Weber H, Ebel R, Edrada R, Thoms C, Schupp P, Bohlin L, Proksch P (2007) Antifouling activity of bromotyrosine-derived sponge metabolites and synthetic analogues.

Mar Biotechnol 9:776-785 
Qian PY, Lau SCK, Dahms HU, Dobretsov S, Harder T (2007) Marine biofilms as mediators of colonization by marine macroorganisms: implications for antifouling and aquaculture. Mar Biotechnol 9:399-410

Qian PY, Xu Y, Fusetani N (2010) Natural products as antifouling compounds: recent progress and future perspectives. Biofouling 26:223-234

Richards JJ, Ballard TE, Huigens RW, Melander C (2008) Synthesis and screening of an oroidin library against Pseudomonas aeruginosa biofilms. Chembiochem 9:1267-1279

Richards JJ, Reyes S, Stowe SD, Tucker AT, Ballard TE, Mathies LD, Cavanagh J, Melander C (2009) Amide isosteres of oroidin: assessment of antibiofilm activity and C. elegans toxicity. J Med Chem 52:4582-4585

Santos Acevedo M, Puentes C, Carreno K, Gomez Leon J, Stupak M, Garcia M, Perez M, Blustein G (2013) Antifouling paints based on marine natural products from Colombian Caribbean. Int Biodeterior Biodegrad 83:97-104

Shai Y (1999) Mechanism of the binding, insertion and destabilization of phospholipid bilayer membranes by alpha-helical antimicrobial and cell non-selective membrane-lytic peptides. BBA-Biomembr 1462:

$55-70$

Shearman JW, Myers RM, Beale TM, Brenton JD, Ley SV (2010) Total syntheses of the bromotyrosine-derived natural products ianthelline, 5-bromoverongamine and jbir-44. Tetrahedron Lett 51:4812-4814

Sipkema D, Franssen MCR, Osinga R, Tramper J, Wijffels RH (2005) Marine sponges as pharmacy. Mar Biotechnol 7:142-162

Sjogren M, Dahlstrom M, Goransson U, Jonsson PR, Bohlin L (2004a) Recruitment in the field of Balanus improvisus and Mytilus edulis in response to the antifouling cyclopeptides barettin and 8,9-dihydrobarettin from the marine sponge Geodia barretti. Biofouling 20:291-297

Sjogren M, Goransson U, Johnson AL, Dahlstrom M, Andersson R, Bergman J, Jonsson PR, Bohlin L (2004b) Antifouling activity of brominated cyclopeptides from the marine sponge Geodia barretti. J Nat Prod 67:368372

Solter S, Dieckmann R, Blumenberg M, Francke W (2002) Barettin, revisited? Tetrahedron Lett 43:3385-3386 
Sonak S, Bhosle NB (1995) A simple method to assess bacterial attachment to surfaces. Biofouling 9:31-38

Stowe SD, Richards JJ, Tucker AT, Thompson R, Melander C, Cavanagh J (2011) Anti-biofilm compounds derived from marine sponges. Mar Drugs 9:2010-2035

Svenson J (2013) MabCent: Arctic marine bioprospecting in Norway. Phytochem Rev 12:567-578

Tadesse M, Gulliksen B, Strom MB, Styrvold OB, Haug T (2008) Screening for antibacterial and antifungal activities in marine benthic invertebrates from northern Norway. J Invertebr Pathol 99:286-293

Tadesse M, Strom MB, Svenson J, Jaspars M, Milne BF, Torfoss V, Andersen JH, Hansen E, Stensvag K, Haug T (2010) Synoxazolidinones a and b: novel bioactive alkaloids from the ascidian Synoicum pulmonaria. Org Lett $12: 4752-4755$

Takada N, Watanabe R, Suenaga K, Yamada K, Ueda K, Kita M, Uemura D (2001) Zamamistatin, a significant antibacterial bromotyrosine derivative, from the Okinawan sponge Pseudoceratina purpurea. Tetrahedron Lett 42:5265-5267

Thabard M, Gros O, Hellio C, Marechal JP (2011) Sargassum polyceratium (phaeophyceae, fucaceae) surface molecule activity towards fouling organisms and embryonic development of benthic species. Bot Mar 54:147157

Tsukamoto S, Kato H, Hirota H, Fusetani N (1996a) Ceratinamides a and b: new antifouling dibromotyrosine derivatives from the marine sponge Pseudoceratina purpurea. Tetrahedron 52:8181-8186

Tsukamoto S, Kato H, Hirota H, Fusetani N (1996b) Mauritiamine, a new antifouling oroidin dimer from the marine sponge Agelas mauritiana. J Nat Prod 59:501-503

Yamada A, Kitamura H, Yamaguchi K, Fukuzawa S, Kamijima C, Yazawa K, Kuramoto M, Wang GYS, Fujitani Y, Uemura D (1997) Development of chemical substances regulating biofilm formation. B Chem Soc Jpn 70:30613069

Yebra DM, Kiil S, Dam-Johansen K (2004) Antifouling technology - past, present and future steps towards efficient and environmentally friendly antifouling coatings. Prog Org Coat 50:75-104 